\title{
PLANNED BUILDING LAND CONSOLIDATION IN THE CONTEXT OF LAND SUBDIVISION OF A UNIQUE PLOT
}

\author{
Amorino Poropat
}

Original scientific paper The model of planned building land consolidation has been determined, representing a structural rule of spatial planning and technical sciences contribution to the field of architecture and urbanism. Empirical and mathematical methods were applied. The planned land consolidation results represent a combined process of application of expression of equations and of the parts of the spatial planning document regarding the manner in which ownership is arranged in the scope of a unique plot. Ownership arrangement includes even subdivision of building land surface areas of both private and public interests. Private interest land is divided into surface areas intended for the same purpose. Some of them are shaped, both location-wise and according to their size, into pieces of land in private ownership. Public interest land is, in one piece, taken out for communal plots and for the competent government authority. Following the adoption of the said planning document, the defined ownership pieces of land and, in some cases, also co-ownership ones are subdivided and entered into the Land Register and Land books.

Keywords: building land; building plot; communal plot; planned consolidation; unique plot

Planska komasacija građevinskog zemljišta u načinu parcelacije jedinstvene parcele

Izvorni znanstveni članak

Utvrđen je model planske komasacije građevinskog zemljišta, a predstavlja jedno strukturno pravilo prostornog planiranja i doprinos je tehničkih znanosti u polju arhitekture i urbanizma. Primijenjena je empirijska i matematička metoda. Rezultati planske komasacije su kombinirani postupak primjene izraza jednadžbi i dijelova dokumenta plana prostornog uređenja u načinu sređivanja vlasništva u obuhvatu jedinstvene parcele. Sređivanje vlasništva uključuje diobu površina građevinskog zemljišta privatnog i javnog interesa. Zemljišta privatnog interesa se dijele na isto-namjenske površine. Pojedine istonamjenske površine, primjenom jednadžbi i brojčanih podataka iz spomenutog plana se ravnomjerno oblikuju, položajno i veličinom vlasničkih komada zemljišta za parcelaciju i uknjižbu. Plansko zemljište javnog interesa se ravnomjerno iz površina suvlasništva odvaja za komunalne parcele, parcelira i knjiži za nadležno tijelo vlasti.

Ključne riječi: građevinska parcela; građevinsko zemljište; jedinstvena parcela; komunalna parcela; planska komasacija

\section{Introduction}

This article is the second part of building land consolidation or the way in which its first part has been implemented, scientifically processed and published in the magazine "Geodetski list" [1]. The first part of the said land consolidation consists of activities and mediation of legal entities and technical field entities for collection of building land cadastral plots from all kinds of ownerships into a unique plot co-ownership. The unique plot implementation includes the terms of procedural work for land consolidation, starting from property owners, whether it concerns physical or legal entities, to legal documentation and elaborates, which clearly and practically develop equations for assembly of the land consolidation mass, including its registration. Prior to the preparation of the urban development plan or the detailed plan, the properties, other buildings and permanent plantations, without the land itself, form a part of terrain rehabilitation, if it is not in compliance with the planning zone purpose. Terrain rehabilitation, unless subject to regulatory determination, encompasses valuation of the said properties with the exception of the land itself, all at the cost of the competent authority.

The second part of land consolidation is a planned consolidation or fragmentation of building land in the conditions of the co-ownership property community.

The reason for this scientific paper is the author's motivation and wish to, both theoretically and practically, determine a balanced [2] model of the planned building land consolidation. The said paper is of relevance for the science, the local authority, as well as for legal and physical entities and for both competent administration bodies and land consolidation users.

In the scope of the unique plot, implementation and even allocation of ownership of building land are researched in the conditions of detailed surface area purpose in settlements of individual residential construction.

The aim is to determine planned consolidation of building land in undeveloped parts of the settlement, by which a co-ownership unique plot is evenly subdivided into ownership pieces of land for undefined forms of building plots and, applying a unique rate, land surface area for communal plots is taken out.

\section{Methodology}

The methodology of this scientific research paper is conducted through three sections. In the first section of this paper a review will be given of relevant papers with retrospection on the significance and problem in the implementation of the present mode of land consolidation, terminology structure, as well as the application of the relevant legislation of the Croatian state and some of the regulations outside Croatia.

The second section is analytical and experimental. On the basis of provisions from the Programme of planning zone arrangement and Contract of establishment of co-ownership property community from the first part of the land consolidation, as well as a base for substitution of dedicated surfaces from the plan graphic illustration planned land consolidation and subdivision are carried out. 
The processing of a unique plot begins with a spatial planner's well-conceived work in the shaping of the surface and belt plot purposes, as well as their relationships on the ground surface area. Empirical and mathematical methods were applied. Empirical method relates to the process of elaboration of a planning document in coordination between the spatial planner and the property owner, as well as the author's years-long experience in the role of the main executor of the gradual work in preparation, adoption and implementation of spatial planning documentation through the competent administrative and local authority bodies.

In this article, the mathematical method includes the application of markings for substitution of particular dedicated surface areas through the method of implementation of the said land consolidation and subdivision. The method of their implementation is the calculation of the numerical data of order, surface areas, purpose, shares, ratios and uniformity.

The procedures for planned building land fragmentation are: firstly, surface plots are separated from belt plots, then the same-purpose surface areas are separated, followed by their ownership fragmentation, but not less than the permitted surface of the building plot.

In the scope of the surface plots, there are undefined building plots of the same surface area purpose and they can also differ. If a surface plot which contains different planned uses of surfaces is in question, then the criteria, especially for each purpose, are the same. This means that the percentage co-ownership shares of the surface are the same for allocation into ownership or co-ownership, both for same-purpose units and their same-purpose parts.

The third section is the perspective or illustration of data for equal ownership allocation.

A random sample of the Planning zone from the residential settlement in Vrsar was chosen as an extract from a part of the Detailed urban plan (Detailed plan of arrangement) for the Residential settlement Vrsar-Istok [3] (Fig. 1). The surface area of the scope of the family construction settlement is 5,84 ha and it was planned as undeveloped building land, owned by the "Municipality", where there were shrubs and evergreen vegetation.

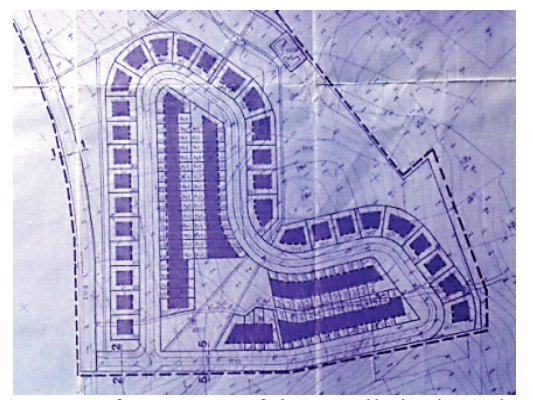

Figure 1 Extract from a part of the Detailed urban plan for the Residential settlement "Vrsar-Istok" [3]

The residential settlement was constructed through the "Solidarnost" residential co-operative. The said sample is suitable for the simulation of surface areas belonging to various property owners and a solid basis for expression of the research results with application of the aforementioned methods in the processing of the title topic and the goal set in the introduction.

Research results follow.

\section{Historical and theoretical aspects of building land consolidation}

\subsection{Terminology structure}

In planned building land consolidation or building land fragmentation, surface plots and belt plots can be distinguished [4].

Surface plots are building land surface areas used for building plots.

Belt plots are building land surface areas used for the settlement communal arrangement.

A unique plot or land consolidation mass is a coownership property community on the surface area of a single cadastral plot.

In settlements of family or other buildings building plots are of private interest, of both physical and legal entities, and can be classified into economic or social activities. The building plots of the said activities are of the related purposes for construction of houses (buildings), public, religious, business, administrative, economic and other buildings, as well as towers, etc. In particular, social activities are a kind of public purpose and belong to the group of employees in the manner that their work activities are of public or other interest, but not the plot of land on which their buildings are situated. From the aspect of land consolidation, a land plot or a building plot for social activities is of a private interest of the employees, as it is not intended for communal plots in the way that they serve other building plots communally or infrastructurally.

Communal plots are public surface areas of arranged ground in a settlement, such as road plots (streets, squares, public parking) and especially the plots for recreation at the level of smaller parks, children's playgrounds, etc. They serve the purpose of traffic and horticultural arrangements of the said public surface areas in the manner that their road arrangement with infrastructural connections (roads, electricity, water, gas, drainage and other), serve the building plots.

The land subdivision elaborate turns building and communal plots into cadastral plots.

\subsection{Significance of land consolidation}

In practice so far, building land consolidation has been based on property evaluation (land, buildings, etc.), existing cadastral plots and on the basis of the Detailed plan of arrangement. The exception is the solution of a single owner in the Planning zone scope or an agreed property subdivision. In the public concern and manner of use of building land, policies of two states, namely of Israel and the Netherlands, which have high population density, are compared. The prices of the land and flats [5] in the Netherlands are very close to production costs, as developmental profits are small on both the land and residential construction. The prices of the said costs in Israel are above the value of the production, thus making the developmental potential considerably higher. At the world level, land rent [6] is most represented as compensation for building land. Land intended for roads and public interest are taken out for the benefit of the competent authority and the rest is subdivided into ownership units or compensation is provided in cash. 
Up to now, the method of building land consolidation was based on the allocation of the quantity of building plots, as shown in the land subdivision elaborate (Fig. 2). For certain owners within the said land consolidation, the subdivision and allocation of building plots was carried out through a competent commission.

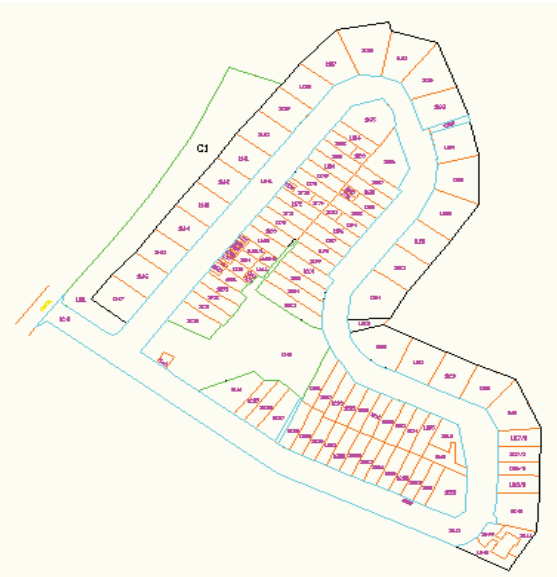

Figure 2 Extract from land subdivision elaborate for the part of the Residential settlement Vrsar-Istok [7]

On the example of German legislation, Master of Construction Vladimir Krtalić describes the method of implementation of urban land consolidation in Bavaria.

The book Systems of Spatial Planning and Use [8], contains markings for land evaluation and differs from this paper concerning equation markings without land prices. "Urban land consolidation, a mechanism of the public construction law, is a means of communal policy which the countries of Central European local selfgovernment units, during the $20^{\text {th }}$ century, used the most and which they still use in the process of building land arrangement. By urban consolidation, a planned, purposeful and economically justified urban surface planning and adjustment of private and public interests as well as ownership right protection are facilitated, but not the geometry of ownership" [9].

A concise review of the implementation of urban land consolidation follows. After the Urban planning and Implementation document has been adopted, it is possible to implement urban land consolidation in three ways: by means of arrangement of boundaries, allocation of entered private land according to measures of value and according to surface area measures.

Arrangement of boundaries includes agreement with the owner concerning the allocation of plots of private interest and a free cession of communal plot land to the local self-government unit. As the said plan for arrangement of boundaries is prepared on the basis of the existing cadastral plots and predominantly for agricultural production, there is a very small probability that the planned building plots are subject to even allocation, as they are shaped as groups of plots of the same or approximate sizes, in accordance with the types of construction or surface area purpose.

The method of implementation of urban land consolidation through measures of value and surface area measures includes evaluation of land consolidation bulk for entered private land and estimate of the value of building plots, shaped in accordance with the Urban
Planning and Implementation document. According to the said document, the surface areas of the land intended for communal plots are ceded to the local self-government units without compensation. The estimate of the value of building plots $\left(75 € / \mathrm{m}^{2}\right)$ is $50 \%$ larger than the estimate of the entered private land $\left(50 € / \mathrm{m}^{2}\right)$. The quoted difference in estimate is such that the owner gets the building plot surface area reduced by the surface area of the communal plots and a part of the surface area in the value which belongs to the local self-government unit. Practically, through the competent authorities, the building plot surface areas are valued at a higher price, which results in reduced surface areas of the land of private interest.

The method of implementation of surface area measures is similar to the one of measures of value, with the difference that surface area contribution is determined. "Surface area contribution is determined on the basis of a quotient of the increased value and the value of the land entered for allocation". The quotient in the numerator makes the calculation of the differences in the price of a $\mathrm{m}^{2}$ of the entered private land and the planned building plots and their product with the surface area composed of the bulk of the building plot land. The quotient in the numerator makes the product of the surface of the bulk of the building plots and their price per $\mathrm{m}^{2}$. The contribution of surface areas is a calculation of the value of the said quotient and its product with the surface area of the land in the scope of the said plan. The communal plot surface areas are reduced by the surface area contributions, as well as real allocated surface areas and monetary differences. Practically, the calculations of the said quotient and its product with the related land surface area is $1 / 3$ of the surface area in the plan scope and makes an increased surface area of the communal plots, and the remaining areas are building plot surface areas.

In the process of land subdivision, apart from estimated value compensation, plots of public interest are allocated. Their share of surface area for construction of "buildings and installations of technical urban infrastructure" is $10 \%$ or $30 \%$ at the most. This larger percentage refers to undeveloped land in the scope of the new Urban Planning and Implementation document and the smaller percentage to partially developed areas. In the implementation of land subdivision, the said document forms a compulsory basis for the process of issue of planning permissions.

It can be concluded from the summarised description of urban land consolidation that, in a simple procedure and free of charge, communal plots are ceded to the competent local self-government units. A unique price of building plot surface areas is present, in the manner that the differences in the value between added value of the entered private land and building plots are settled in cash. In resolving of communal plots, the competent authority's work is objectively simple, efficient and requires a minimal amount of time for realisation. Monetary settlement means deviation from an equal allocation of building plots and problems also may occur related to the fact that, on one hand, land is ceded without compensation and, on the other, having to monetarily settle the additional difference from the estimate. 


\subsection{Urban land consolidation of Croatia (2007 - 2013)}

The land consolidation procedure - request for initiation of the procedure, decision on implementation of land consolidation procedure, determination of the land market value, clients' statements and establishment of the exact state of the property, allocation of building and other plots, monetary compensation, formation of developed building plots, decision on land consolidation and execution of the decision on land consolidation are the titles relevant to clauses $137 \div 176$ of the Law on Spatial Planning and Construction [10]. Conditionally, according to the said Law, the subject of land consolidation is all land in the area of land consolidation, except: "building plots, developed in accordance with the detailed plan of arrangement in force; undeveloped plots, having the shape and the size which are determined by the Detailed plan of arrangement in force; developed plots which, by means of alterations to their shapes and surface areas, can be adjusted to the Detailed plan of arrangement in force and plots on which buildings are constructed without planning permissions, i.e. another corresponding document in accordance with the Detailed plan of arrangement which, by alterations to their shapes and surface areas, can be adjusted to the said Plan".

Undeveloped plots are cadastral plots in the plan pending planned construction. Why make difference in the scope of the detailed plan of arrangement when it comes to allocation of use and purpose surface areas for undeveloped plots? The differences for undeveloped plots in the planning of building plots lie in irregularities in the provisions of regulations for urban land consolidation. The size of the land is reduced by the surface areas intended for public use for property owners whose cadastral plots differ from the planned building plots, while for other owners this is not the case just because their cadastral plots are identical to the building plots. Due to this, some owners are privileged while some others are not and one can say that the regulation irregularities are such that they, directly or indirectly, negatively affect property owners. Consequently, with the said building land consolidation terms, it does not make it easy for plan designers to plan functional and optimal space solutions. In such circumstances regarding regulations, land owners in the process of preparation of planning documentation considerably influence the spatial planner in order to preserve the position and the size of their cadastral plots, regardless of functional form-fitting solutions for roads, recreation and other surface area uses. In principle, owners are looking for a planned preservation of their cadastral plots as, in that case, proportional reduction of their property on account of the areas allocated for public use is not possible. This means that, in the process of urban land consolidation, the reciprocity rules do not apply, as some owners benefit from it as privileged, while others, whose cadastral plots are reduced, stand to lose as they get reduced building plots, despite monetary compensation for differences in the size of surface areas that are of rather questionable evaluation of dedicated land, in accordance with the method of property valuation from year 1984. [11].

Other building plots, which are not destined for public use, are allocated to owners, i.e. land consolidation participants, in line with the regulatory provisions, taking into consideration a proportional decrease in their surface area by up to $33 \%$ in relation to the public purpose land surface areas. Owners who do not meet conditions for allocation of a building plot are compensated monetarily. In the scope of land consolidation, how can plots be allocated to the owners when public purpose land surface areas are larger than $33 \%$ ? Implementation is disputable also if it concerns the question of housing accommodation and there is a lack of surface area for allocation of building plots.

\subsection{Partial planned land consolidation}

The Law on State Survey and Real Estate [12] facilitated gradual establishment of the real property cadastre by means of individual entry. Individual entry in the real property cadastre is in line with the regulations [13] from the aforesaid Law. The final result of the individual entry in the real property cadastre should be identical to the result of the cadastral survey [14], which is also in line with the land consolidation scope.

Most recently, so-called "Property institutes of building land development" have been proscribed by the Spatial planning Law [15]. It is important to emphasise the following: "The land owner to whom the said development is of use, or any other interested person who enters an agreement on the financing of the development of the building land with the local self-government unit, may bear the cost or a part of the costs required for the preparation of the spatial plan of arrangement or construction of the communal infrastructure". The said contract also contains five-point provisions, of which the last point and three paragraphs do not need to be quoted, as they are publicly available, thus being omitted from this text. "Transfer of land in the ownership of the local self-government unit", "Obligation to sell land" and "Right of pre-emption" are proscribed. The proscribed provisions are conditional and mainly directed towards a single owner or another interested person who enters the said agreement with the local self-government unit. Practically, one or several cadastral plots are dealt with as a unity of building land for a single owner and implementation of building land for several cadastral plots and several different owners is questionable. Spatial planning structural rules and the manner of building land arrangement are missing, so the said Property institute is one of the solutions which is lacking in the aforementioned rules.

Partial or fragmentary planned land consolidation is carried out individually for ownership expropriation on parts of the communal plots. The Rules on Methods of Property Valuation [16] from the year 2014 provide a solid basis for valuation of the said land for the settlement communal arrangement.

However, the procedure for issue of planning permissions with or without urban land consolidation is based on a separate document i.e. the location permit, also known as location conditions and urbanistic and technical conditions, so the implementation of land subdivision of communal plots is dealt with sporadically, partially simply, or not at all. Sporadically in the way that competent administrative authority bodies conduct 
expropriation proceedings, in line with the regulatory expropriation [17]. In the course of the said proceedings, negotiations take place about the land price or exchange and, most often it concerns court proceedings that take a long time to resolve. Partially simply is when, on the part of a planned road, an owner gives up his property land for the benefit of the local self-government unit. Not at all is when the said plan remains unrealised, as spatial planning regulations frequently change in Croatia, thus also resulting in changes to the associated spatial planning documents. Joined to this is also the land of a planned road, which contains several cadastral plots belonging to different owners. In dealing with communal plots, the competent authority body's work can only be complicated, inefficient and long-term, over an indefinite time period for realisation.

\section{Planned fragmentation of a unique plot}

The results of this research are shown hereafter.

\subsection{Co-ownership of a unique plot}

In one part of the planning zone for construction of the residential settlement, a unique plot was created (Fig. $3)$.

The unique plot ownership and co-ownership shares are worked out using the following equation: $U_{\mathrm{vx}}=100 \times k \times \frac{F_{\mathrm{ix}}}{J_{\mathrm{p}}},[1]$. In our case $k=1$, as land surface areas from special geodetic lining data and land registry extracts are identical. By applying the International system of units [18] and associated markings, the altered expression of the said equation for unique plot ownership shares reads:

$$
S_{\mathrm{o}}=\frac{A_{\mathrm{o}}}{A_{\mathrm{u}}}
$$

where:

$S_{\text {o }}$ - Share of the ownership or parts of the ownership property in the co-ownership of a unique plot for physical and legal entities; small "o" is the ordinal number and the associated identity of the physical or legal entity coowners.

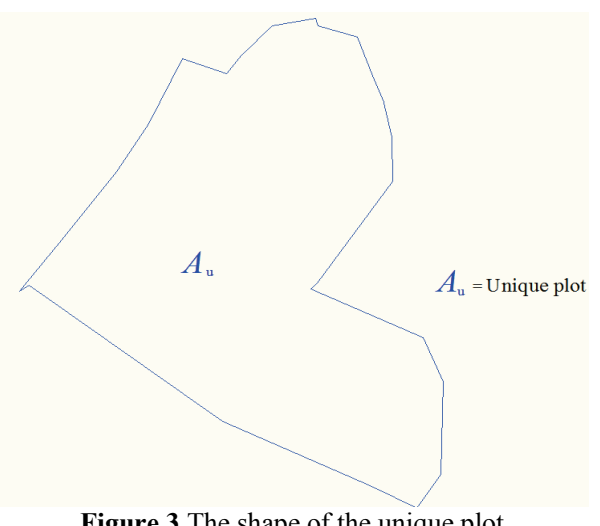

Figure 3 The shape of the unique plot

$A_{\mathrm{o}}$ - the surface area of the land in co-ownership for physical and legal entities and the marking of small "o" is the same as the previous one, $\mathrm{m}^{2} . A_{\mathrm{u}}$ - unique plot surface area, $\mathrm{m}^{2}$, marking small " $\mathrm{u}$ " - identity for the markings of cadastral plots and associated cadastral municipality. $\times$ product.

In the process of elaboration of the spatial planning documentation (Detailed plan of arrangement), apart from the mandatory attachments, there is also the data from Tab. 1.

The data in Tab. 1 are extracts from the documents of land registry and cadastral and geodetic elaborates and their calculations of sizes form the basis for the planned building land consolidation.

Table 1 Co-ownership of a unique plot

\begin{tabular}{|c|c|c|c|c|c|}
\hline \multicolumn{2}{|c|}{$A_{u}$} & Ordinal number & Co-owners & $A_{\mathrm{O}}$ & $S_{\mathrm{o}}$ \\
\hline \multirow{6}{*}{ 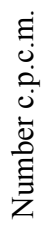 } & \multirow{6}{*}{ 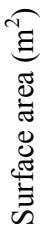 } & 1 & Identity card & $A_{1}$ & $S_{1}$ \\
\hline & & 2 & $-1-$ & $A_{2}$ & $S_{2}$ \\
\hline & & 3 & $-1-$ & $A_{3}$ & $S_{3}$ \\
\hline & & $-/-$ & $-1-$ & $-/-$ & $-/-$ \\
\hline & & $-1-$ & $-1-$ & $-/-$ & $-/-$ \\
\hline & & $-/-$ & $\mathrm{O}$ & $A_{\mathrm{o}}$ & $S_{\mathrm{o}}$ \\
\hline
\end{tabular}

Markings: c.p. - cadastral plot; c.m. - cadastral municipality; $A_{u}$, $A_{\mathrm{o}} S_{\mathrm{o}}$, are markings for the identity and sizes $\left(\mathrm{m}^{2}\right)$ for the scope of the unique plot surface area and some co-owners of the building land from the Eq. (1).

\subsection{Division of a unique plot}

The unique plot is physically split to form two surface area units. One surface area unit is a surface plot and the other one a belt plot. The surface plot contains separate parts, but the expression of their surface areas equals the product of all the parts as a single unit (Fig. 4). By substituting one unit of surface areas from the plan graphical illustration with the equation markings results in the method of calculation of numerical data for the said surface and belt plots (Eqs. (2), (3) and (4)).

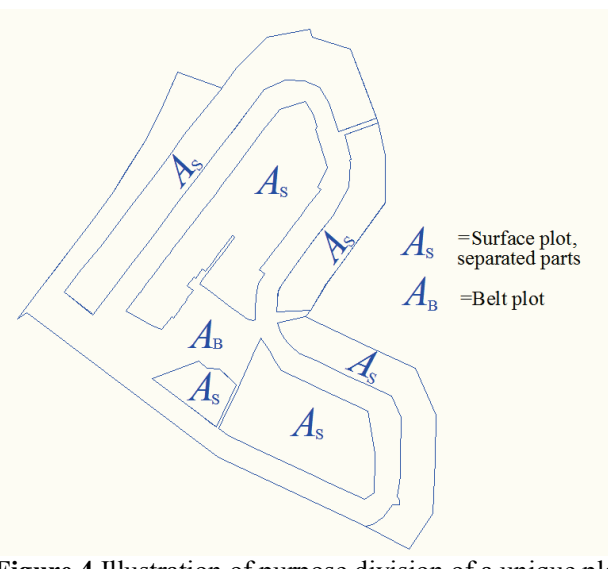

Figure 4 Illustration of purpose division of a unique plot

Using the aforesaid methodology of elaboration of the planning document for the division of a unique plot into belt and surface plots and applying the markings of numerical measures (shares and surface areas) the expressions of the following equations are determined:

$A_{\mathrm{u}}=A_{\mathrm{S}}+A_{\mathrm{B}}$

where:

$A_{\mathrm{u}}$ - the same as the expression of the Eq. (1) 
$A_{\mathrm{S}}$ - surface plot surface area and small "S" is the marking for the surface plot within the unit;

$A_{\mathrm{B}}$ - belt plot surface area and small "B" is the marking for the belt plot within the unit.

The shares of surface and belt plots in the unique plot can be illustrated as follows:

$$
S_{\mathrm{B}}=\frac{A_{\mathrm{B}}}{A_{\mathrm{u}}}
$$

where:

$S_{\mathrm{B}}$ - the belt plot share in the unique plot surface area;

$A_{\mathrm{B}}$ - the same as the expression of the Eq. (2);

$A_{\mathrm{u}}$ - the same as the expression of the Eq. (1).

$$
S_{\mathrm{S}}=\frac{A_{\mathrm{S}}}{A_{\mathrm{u}}}
$$

where:

$S_{\mathrm{S}}$ - the surface plot share in the unique plot surface area; $A_{\mathrm{S}}$ - the same as the expression of the Eq. (2); $A_{\mathrm{u}}$ - the same as the expression of the Eq. (1).

\subsection{Purpose of belt and surface plots}

The belt plot is the synonym for communal plots, intended for road surface areas, as well as installation of cables and pipe work of the associated infrastructure. The characteristics of the communal plot are reflected in the use, maintenance and opening of permanent jobs and, altogether, they serve the surface plot, with charges for services provided. The surface plot contains building plots, certain surface purposes and they are street and infrastructurally-wise served by the belt plots, for which the owners pay a corresponding compensation. Fig. 5 shows their shape, size, location and purpose.

The markings for calculation of numerical data for the purpose of communal and building plots are expressions of the Eqs. (5), (6) and (7).

By application of expressions of the said equations, it is possible to divide communal plots into the plots of roads and recreation, but that is not commendable, as the said share of the development of public interest belt plot is ceded to the competent authority unit. If the belt plot is divided into the aforesaid arrangements, then the small block letter " ${ }_{\mathrm{B}}=$ the ordinal number of arrangement: " $\mathrm{al}$ ", " ${ }_{a 2}, "{ }_{a 3} ", \ldots()_{a}$ - road plot and recreation plot: ${ }_{a 2}$ protective greenery and $\mathrm{a}_{3}$ - park greenery). The purpose of the surface plot is divided into the ordinal number of surfaces and the associated ordinal number of surface area purposes. In the said equations, the marking of small "s" the ordinal number of the surfaces "c1", "c2", "c3",., , and the associated marking in the exponent is the ordinal number of the surface area purposes: "p1", "p2" ,... There are many surface area purposes. In this article, ordinal numbers are used due to the generalisation of the application of the said surface area purposes. They can be substituted by the identification of surface area purposes from the said plan and it is best to scientifically process them, ordinally classify them and arrange the application of the purpose markings in a regulatory manner.
If the purpose of the unique plot surfaces with several different surface area purposes is in question, then, in proportion to their shares, all co-owners participate in each individual building surface area purpose (Fig. 5).

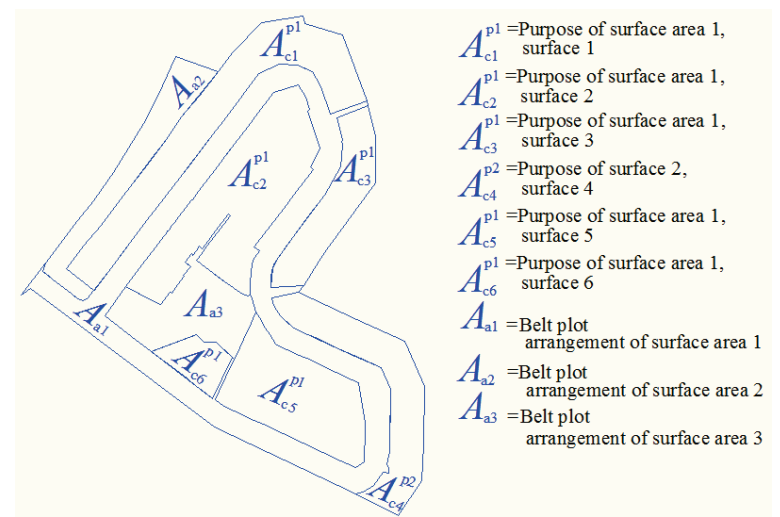

Figure 5 Illustration of a unique plot and different surface area purposes

Certain shares of surface area purpose from the corresponding surfaces can be illustrated by the following equation expression:

$S_{\mathrm{S}}=\frac{A_{\mathrm{S}}}{A_{\mathrm{u}}}=\frac{A_{\mathrm{c} 1}^{\mathrm{p}}}{A_{\mathrm{u}}}+\frac{A_{\mathrm{c} 2}^{\mathrm{p} 2}}{A_{\mathrm{u}}}+\ldots \frac{A_{\mathrm{c} 4}^{\mathrm{p} 2}}{A_{\mathrm{u}}}+\cdots$

where:

$S_{\mathrm{S}} ; A_{\mathrm{s}} ; A_{\mathrm{u}}$ - the same as the expression of the Eq. (4);

${ }_{\mathrm{c} 1}^{\mathrm{p} 1} ; A_{\mathrm{c} 4}^{\mathrm{p} 2}$ - the same as the markings (Fig. 5). Purposes are possible for the first: ${ }^{\mathrm{p} 1}$ - residential and for the second: ${ }^{2}$ - tourist villas.

The first purpose can be illustrated by the following equation expression:

$A^{\mathrm{p} 1}=A_{\mathrm{c} 1}+A_{\mathrm{c} 2}+A_{\mathrm{c} 3}+A_{\mathrm{c} 5}+A_{\mathrm{c} 6}$

where:

$A^{\mathrm{p} 1}-$ first surface of one purpose

$A_{\mathrm{c} 1}+A_{\mathrm{c} 2}+A_{\mathrm{c} 3}+A_{\mathrm{c} 4}+A_{\mathrm{c} 5}+A_{\mathrm{c} 6}$ - surface area from the product of the same-purpose surfaces.

The second purpose can be illustrated by the following equation expression:

$A^{\mathrm{p} 2}=A_{\mathrm{c} 4}$

where:

$A^{\mathrm{p} 2}$ - second surface area of the second purpose; $A_{\mathrm{c} 4}$ - surface area of the fourth surface.

\subsection{Ownership land fragmentation}

The surface areas in the scope of certain surfaces of identical purposes are divided into pieces of land of a corresponding surface area, according to the Eq. (8), so that the calculation of land surface area for a particular owner corresponds to the size of his/her share. According to their surface area location, shape, purpose and size, 
pieces of land for certain owners are determined by the land consolidation subdivision plan (Fig. 6).

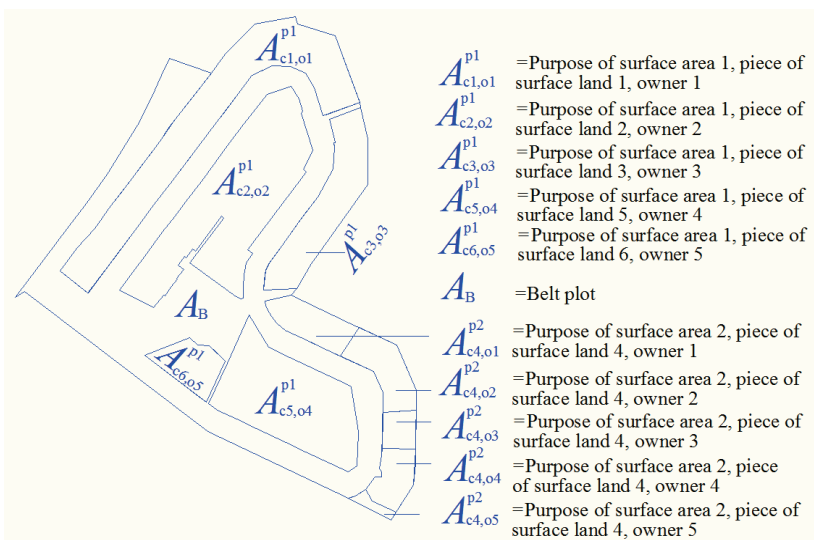

Figure 6 Land consolidation subdivision plan

At the level of a specific purpose of the surface plot for a particular owner, the surface area of the land in one piece can be illustrated by the following equation expression:

$A_{\mathrm{c}, \mathrm{o}}^{\mathrm{p}}=A^{\mathrm{p}} \times S_{\mathrm{o}}$

where:

$A_{\mathrm{c}, \mathrm{o}}^{\mathrm{p}}$ - surface area of the land in one piece for a specific purpose and a particular owner and the marking small $\mathrm{p}_{-}$ ordinal number of surface area purpose $\left({ }_{\mathrm{p} 1, \mathrm{p} 2, \mathrm{p} 3 \ldots}\right)$; the marking small $c_{c}$ - ordinal number of the surface, $\left({ }_{\mathrm{cl} 1, \mathrm{c} 2, \mathrm{c} 3 \ldots}\right)$; the marking small $\mathrm{o}$ - ordinal number of the owner $\left({ }_{01,02,03 \ldots)} ; A^{\mathrm{p}}\right.$ - surface area purpose;

$S_{\mathrm{o}}$ - the same as the expression of the Eq. (1).

In the event that some owners do not realise a piece of land in the surface area of the building plot, then the surface area marked " $A_{\mathrm{c}, \mathrm{o}}^{\mathrm{p}}$ " can be in co-ownership.

\section{Planned land consolidation implementation}

The land consolidation subdivision plan is an integral part of the associated document of spatial planning and encompasses pieces of building land, within which there can be one or several building plots. Certain parts of the land are allocated into ownership units, in accordance with the said contract. Owners also take part in the phase of elaboration of the draft of the said document, in the way that they co-ordinate the interest allocation of the land and, to preventatively see the location, the shape, the size and the purpose of their planned property. The draughtsman evidences the co-ordinated interest in the way that all owners or their attorneys initial the agreed property allocation (rough location and purpose) on the special drawing or on the separate copy of the plan. If some owners submit a written objection and refuse to initial the said property allocation, as they are asking for different allocation terms, then a Land consolidation commission is established composed of three members who are appointed by the competent authority body. The Commission president is the spatial planner, in the role of the leader of elaboration of the said plan and the remaining two are independent authorised experts, of which one is from the field of geodesy and the other from the legal profession. In the event that the objection is not accepted, because other co-owners or communal standards are opposed to it, then the said Commission decides on a suitable solution. If the said standards are not legally stipulated, then measures of noise protection, fire protection, environmental protection and permitted capacities of use must not be opposed to it. The said Commission's decision is final.

On the basis of the said land consolidation plan, a land consolidation subdivision elaborate is prepared, as a basis for its registration in the competent land cadastre and associated land registers. Arranged and registered ownership of pieces of land, carried out in a planned way, is the end of the planned building land consolidation. In further process of implementation of the spatial planning document, the said pieces of land are subdivided into building plots at the owner's disposal, both time-wise and financially, in the realisation of the planned construction. Deadlines for the commencement of construction of building plots, as well as other owners' rights and obligations, are agreed in a regulatory manner.

Ownership pieces of land are determined by application of numerical data relating to ownership shares from the unique plot, as well as the markings of the expressions of the said equations (Tab. 2).

In the said Tab. 2, numerical data and markings are systemised: owners' ordinal number, particular surface areas of ownership shares and their sizes, the volume of surface and belt plot shares, the surface area of both purposes, the pieces of building land individually per each owner, as well as the unique plot surface area. The fragmentation of the said land is carried out evenly, by application of the numerical value of ownership shares and plots of both surface area purposes. By applying the flat rate $(41 \%)$ or the numerical value $(0,41)$ for reduction of the land entered into the unique plot, a calculation is separately provided of the communal plot which all owners individually cede. In relation to the unique plot surface area, the communal plot shares are as follows: road plots $(26,63 \%)$, recreation plots: protective greenery $(6,77 \%)$ and park greenery $(7,54 \%)$. In comparison with the introductory limited values of other regulations for public interest plots $(10,30$ and $33 \%)$, in our case, a considerably larger share of communal plot surface areas is noted. The reason for this is the freedom of the Spatial planner's creative work, even allocation of surface areas and a larger surface area for recreation ground for a better quality of living within the settlement. In addition to this, owners are allocated pieces of building land, arranged in a planned manner, and the cost of portions of property which they cede to the competent authority body includes the communal development and the realisation of the said document, as well as the preparation and implementation of the subdivision land consolidation elaborate. Communal plots are taken out in the ownership of the competent authority body, in keeping with the determined methodology. Otherwise, if the road and recreation land in the settlement is for sale or remains private property, an owner can then prevent another owner from using it. For this reason, communal 
land plots, created from the unique plot and ceded to the competent authority body, are not for sale and they should not be either purchased or sold. With the said authority, building plot owners should regulate their rights and obligations related to unhindered use, construction and maintenance of communal plots. For proper functioning and service of communal plots, new service jobs are required; thus the associated land gains more in significance and price than public interest. On the basis of the aforesaid, the following conclusions are possible here below.

Table 2 Expression of numerical data from planned building land consolidation

\begin{tabular}{|c|c|c|c|c|c|c|c|c|c|}
\hline $\begin{array}{c}\text { Ord. } \\
\text { no. }\end{array}$ & $A_{\mathrm{o}}\left(\mathrm{m}^{2}\right)$ & $S_{\mathrm{o}}$ & $S_{\mathrm{S}}$ & $S_{\mathrm{B}}$ & $A^{\mathrm{p} 1}\left(\mathrm{~m}^{2}\right)$ & $A^{\mathrm{p} 2}\left(\mathrm{~m}^{2}\right)$ & $A_{\mathrm{c}, \mathrm{o}}^{\mathrm{p} 1}\left(\mathrm{~m}^{2}\right)$ & $A_{\mathrm{c}, \mathrm{o}}^{\mathrm{p} 2}\left(\mathrm{~m}^{2}\right)$ & $A_{\mathrm{B}}\left(\mathrm{m}^{2}\right)$ \\
\hline o1 & 16880 & 0,29 & 0,59 & 0,41 & 29167 & 5316 & 8432 & 1537 & 6911 \\
\hline 02 & 18466 & 0,32 & 0,59 & 0,41 & 29167 & 5316 & 9225 & 1681 & 7560 \\
\hline 03 & 7427 & 0,13 & 0,59 & 0,41 & 29167 & 5316 & 3710 & 676 & 3041 \\
\hline 04 & 12814 & 0,22 & 0,59 & 0,41 & 29167 & 5316 & 6401 & 1167 & 5246 \\
\hline o5 & 2800 & 0,05 & 0,59 & 0,41 & 29167 & 5316 & 1399 & 255 & 1147 \\
\hline$A_{\mathrm{u}}$ & 58387 & & & & & & 29167 & 5316 & 23905 \\
\hline
\end{tabular}

Markings: Ord. No. = ordinal number; (o1-o5) - owners' ordinal number; $A_{\mathrm{o}}=$ surface area of co-ownership in land; $S_{\mathrm{o}}=$ ownership share; $S_{\mathrm{S}}=$ surface plot share in unique plot surface area; $S_{\mathrm{B}}=$ belt plot share in unique plot surface area; $A^{\mathrm{p} 1}=$ one purpose surface area; $A^{\mathrm{p} 2}=$ second purpose surface area; $A_{\mathrm{c}, \mathrm{o}}^{\mathrm{p} 1}=$ surface area of one piece of land for one purpose and one owner; $A_{\mathrm{c}, \mathrm{o}}^{\mathrm{p} 2}=$ surface area of one piece of land for second purpose and one owner; $A_{\mathrm{B}}=$ belt plot surface area; $A_{\mathrm{u}}=$ unique plot surface area.

\section{Conclusions}

Planned land consolidation is a combined procedure of application of equation expressions and parts of the spatial planning document in the context of arrangement of building land ownership. Arrangement of ownership from co-ownership of a unique plot includes planned detachment of ownership pieces of land for construction of buildings at the level of surface plots and detachment of surface areas of building land intended for public arrangement of land at the belt plot level.

At the level of belt and surface plots, the manner in which ownership is arranged is by using the model of planned building land consolidation in realisation of order, regularity, balance, functionality, subdivision and land register ownership status for newly planned pieces of land. The model of planned building land consolidation is a basis for subdivision of building plots for construction of buildings and arrangement of communal plots, in accordance with the spatial planning document. Forming of the said belt and surface plots and planned fragmentation of ownership plots reflect the freedom of the Spatial planners' creative work, in line with this methodology criteria.

The said planned land consolidation differs from the urban land consolidation in the method of implementation and arrangement of ownership. In the manner in which it is implemented, planned land consolidation starts from a co-ownership of a unique plot, as an unarranged ownership relationship and subsequently, in the elaboration of the spatial planning document, it separates the plots of private and public interest, arranging associated ownerships. The method of arrangement of ownership is by application of balance of surface areas without evaluation of the land, as the dimension from the estimation and the dimension from the balance do not go together, as is seen from the process of urban land consolidation. According to the purposes of the surface areas and ownership pieces of land for construction of buildings, ownerships for private interest plots are arranged uniformly. Equally, the surface area of communal plots for public arrangement of the ground in the settlement is uniformly taken out for the competent authority body. Urban land consolidation starts from the owned cadastral plots and evaluation of surface areas and then, on the basis of newly-planned building plots from the spatial planning document, separates plots of public interest and, in some cases, also public purpose plots. The rest are building plots which the Commission allocates to owners, with compensation equalling the difference between the evaluation of the land surface areas prior to and following the elaboration of the spatial planning document.

In land consolidation, the smallest ownership unit of a particular piece of land cannot be smaller than the smallest building plot surface area, which is determined by either relevant regulations or the spatial planning document. Otherwise, if the ownership unit is smaller than the smallest size of the building plot, then it is allocated to the special co-ownership plot, as an ownership share, or monetary compensation is given for the increase in the other share and, in some cases, land is also exchanged.

In this article the following are distinguished: surface areas of public and private interests. The public interest surface areas (streets, parks, etc.) are communal areas or properties of developed and arranged land, on which movement and passage of people are possible without any physical limitations. Their task is to street-wise and infrastructurally serve building plots. Private interest surface areas are building plots on which buildings are constructed, main and ancillary, regardless of their purpose.

Within the surface area of the surface plot, before the ownership pieces of land have been defined, co-owners can mutually exchange their co-ownership parts, regardless of different purposes, in order to create ownership units for the associated building plot.

The said model of planned land consolidation is a structural rule of spatial planning of ownership pieces of building land in combination with drawings and equations, for the purposes of the arrangement of private and public interests, without privileges, unknowns, evaluations, needless administrative work, by which 
current professional, regulatory and scientific imperfections and irregularities will be removed.

Planned building land consolidation is of public interest and its process of elaboration and implementation is coordinated and financed by the competent authority body.

The decision on the adoption of the spatial planning document should be identifying and publicly announced, with directions for its implementation.

\section{Acknowledgement}

This article is intended for planned land consolidation users and its application resolves relationships of land in the inhabitants' harmony of living. It is financed from own funds, realised from the projects conducted by the Institute of Agriculture and Tourism in Poreč.

\section{References}

[1] Poropat, A.; Radolović, A.; Radolović, O. Provedba planerske zone u komasaciji građevinskog zemljišta. // Geodetski list. 67(90), 1(2013), pp. 41-60.

[2] Poropat, A. Glossary of hospitality and tourism industry construction in the hierarchy, classification and shaping of units of purpose. // Tehnički vjesnik-Technical Gazette. 21, 3(2014), pp. 567-582.

[3] Odluka o donošenju Provedbenog urbanističkog plana stambenog naselja Vrsar-Istok, Službene novine ZO Rijeka, 1987, br. 58; 5/90.

[4] Poropat, A. The Land Plot - The Introduction of Planning Script. // Economic Research. 23, 1(2010), pp. 47-59.

[5] The Effects of Land Policy: Quantity as well as Quality is Important. // Urban Studies. 35, 1(1998), pp. 25-44. DOI: $10.1080 / 0042098985050$

[6] Jager, J. Urban Land Rent Theory: A Regulationist Prerspective. // International Journal of Urban and Regional Research, vol. 27.2, Brighton, UK. (2003), pp. 233-249.

[7] Izvod iz parcelacijskog elaborata za dio Stambenog naselja Vrsar Istok, Općina Vrsar, Odjel za geodetske poslove

[8] Krtalić, V. Sustavi planiranja korištenja zemljišta, Novi informator d.o.o. Zagreb, 2004.

[9] Krtalić, V. Urbana komasacija u Bavarskoj. // Hrvatska javna uprava, god. 7. (2007), br. 3, pp. 711-741.

[10] Zakon o prostornom uređenju i gradnji. Narodne novine, 2007, br 76., 38/09., 55/11., 90/11., 50/12., 55/12.

[11] Uputstvo o načinu utvrđivanja građevinske vrijednosti ekspropriranih objekata Narodne novine, br. 52/84

[12] Zakon o državnoj izmjeri i katastru zemljišta, Narodne novine, 1999, br. 128., 153/05., 16/07., 124/10.

[13] Pravilnik o parcelacijskim i drugim geodetskim elaboratima, Narodne novine, 2007, br. 86., 25/09., 148/09.

[14] Stančić, B.; Roić, M. Koncepcijski model pojedinačnog prevođenja katastarskih čestica u katastar nekretnina. // Geodetski list. 1, (2011), pp. 21-36.

[15] Zakon o prostornom uređenju. Narodne novine, 2013, br. 153.

[16] Pravilnik o metodama procjene vrijednosti nekretnina, Narodne novine, br. 79/14.

[17] Zakon o izvlaštenju i određivanju naknade, Narodne novine, br. 9/94, 35/94, 112/00, OUSRH, 114/01, 79/06, $45 / 11,34 / 12$ i $74 / 14$.

[18] Le Système International d'Unités - The International System of Units. LASERplus d.o.o., Zagreb, 2007. ISBN 978-953-6783-04-5.

\section{Author's address}

zsv. dr. sc. Amorino Poropat

Institute of Agriculture and Tourism of Poreč Karla Huguesa 8, 52440 Poreč, Croatia

E-mail: amorino.poropat@gmail.com 